\title{
Effects of Endogenous Neurotransmitters on the in vivo Binding of Dopamine and 5-HT Radiotracers in Mice
}

\author{
Onarae V. Rice, M.A., S. John Gatley, Ph.D., Ji Shen, Ph.D., Craig L. Huemmer, B.S., \\ Renata Rogoz, Ph.D., Onofre T. DeJesus, Ph.D., Nora D. Volkow, M.D., and Andrew N. Gifford, Ph.D.
}

Several studies have indicated that the in vivo binding of $D_{2}$ receptor positron emission tomography radiotracers can, under some conditions, be influenced by competition with endogenous dopamine. The present study was undertaken to compare the extent to which the in vivo binding in mice of radiotracers to other amine neuroreceptors, namely $\mathrm{D}_{1}, 5-\mathrm{HT}_{2 A}$ and $5-\mathrm{HT}_{1 A}$ receptors, can also be modulated by neurotransmitter competition. For dopamine radiotracers we examined $\left[{ }^{3} \mathrm{H}\right]$ raclopride as a $\mathrm{D}_{2}$ radiotracer and $\left[{ }^{3} \mathrm{H}\right] \mathrm{A} 69024$ as a $\mathrm{D}_{1}$ radiotracer. Striatal binding of both radiotracers was substantially reduced by administration of the dopamine releaser, amphetamine, although only at a high dose. $\left[{ }^{3} \mathrm{H}\right]$ raclopride was decreased more than $\left[{ }^{3} \mathrm{H}\right] \mathrm{A69024}$. Dopamine depletion with 4-hydroxybutyrate strongly increased $\left[{ }^{3} \mathrm{H}\right]$ raclopride binding but failed to increase $\left[{ }^{3} \mathrm{H}\right] A 69024$ binding. For $5-\mathrm{HT}$ radiotracers we examined $\left[{ }^{3} \mathrm{H}\right] \mathrm{N}$ - methylspiperone as a $5-H T_{2 A}$ radiotracer and $\left[{ }^{3} H\right] W A Y$ 100635 as a 5-HT 1 radiotracer. Cortical binding of both radiotracers was unaffected by the 5-HT releaser, p-chloroamphetamine. $\left[{ }^{3} H\right] W A Y 100635$ binding was additionally unaffected by 5-HT release with fenfluramine and by 5-HT depletion with $p$-chlorophenylalanine.

In conclusion, of the four radiotracers examined, $\left[{ }^{3} \mathrm{H}\right]$ raclopride binding to $D_{2}$ receptors had greatest sensitivity to changes in endogenous neurotransmitter levels. $\left[{ }^{3} H\right] A 69024$ binding to $D_{1}$ receptors was affected only by neurotransmitter increases. $\left[{ }^{3} \mathrm{H}\right] \mathrm{N}$-methylspiperone binding to $5-\mathrm{HT}_{2 A}$ receptors and $\left.{ }^{3} \mathrm{H}\right] \mathrm{WA} \mathrm{Y} 100635$ binding to $5-\mathrm{HT}_{1 A}$ receptors appeared insensitive to changes in neurotransmitter levels.

[Neuropsychopharmacology 25:679-689, 2001] (C) 2001 American College of Neuropsychopharmacology. Published by Elsevier Science Inc.
KEY WORDS: Positron emission tomography; Dopamine; Serotonin; 5-HT receptors

The brain amine neuroreceptors that can be currently imaged using Positron Emission Tomography (PET)

From the Medical Department, Brookhaven National Laboratory, Upton, NY 11973 (OVR, SJG, JS, CLH, RR, NDV, ANG, JG), and Department of Medical Physics, University of Wisconsin Medical School, Madison, Wisconsin 53706 (OTD)

Address correspondence to: Dr. Andrew N. Gifford, Medical Department, Brookhaven National Laboratory, Upton, NY 11973, Tel.: 631-344-7069, Fax: 631-344-5311, e-mail: gifforda@bnl.gov

Received February 23, 2001; revised April 24, 2001; accepted May 10, 2001.

Online publication: 5/15/01 at www.acnp.org/citations/Npp 051501119 . and Single Photon Emission Computed Tomography (SPECT) are the $\mathrm{D}_{2}$ and $\mathrm{D}_{1}$ dopamine receptors, $5-\mathrm{HT}_{2 \mathrm{~A}}$ receptors and $5-\mathrm{HT}_{1 \mathrm{~A}}$ receptors. Imaging these receptors in the brain is of interest because of their potential role in the cause and/or treatment of several kinds of psychiatric disease, especially in schizophrenia, substance abuse, depression and anxiety-related disorders. These radiotracers have been classically employed to measure the density of receptors and the degree of occupancy by clinical drugs. However, in the case of $\mathrm{D}_{2}$ radiotracers it has recently become apparent it may be possible to use some of these radiotracers to provide an indirect measure of changes in the in vivo extracellular concentration of endogenous neurotransmitter, based 
on the principle that the radioligands will compete with the neurotransmitter for binding to the receptor. High synaptic concentrations of dopamine will result in less radioligand binding whereas lowered synaptic concentration of dopamine will result in more radioligand binding. This phenomenon may prove useful in many studies since by measuring changes in the binding of the radiotracer it may be possible to monitor changes in dopamine levels occurring either as a result of drug treatments or psychiatric diseases. Conversely, in studies where the intention is only to quantify the receptor density, competition of radiotracer binding with the endogenous neurotransmitter can be an additional complication in interpretation of the results from a PET or SPECT study.

The studies performed to date examining competition between endogenous dopamine and $D_{2}$ radiotracer binding have involved both rodent studies and primate and human PET studies. For example, in studies in mice, increases in synaptic dopamine produced by amphetamine administration have been found to produce decreases in the in vivo striatal binding of $\left[{ }^{3} \mathrm{H}\right]$ raclopride, while dopamine depletion with reserpine treatment or gamma-butyrolactone causes significant increases in binding (Ross and Jackson 1989a; Ross 1991; Young et al. 1991). In PET and SPECT studies in primates and humans increases in the levels of synaptic dopamine produced by administration of either amphetamine or dopamine uptake inhibitors such as cocaine and methylphenidate have similarly been found to produce modest decreases (10-40\%) in the binding of $\left[{ }^{11} \mathrm{C}\right]$ raclopride and or of $\left[{ }^{123} \mathrm{I}\right] \mathrm{IBZM}$ (Innis et al. 1992; Volkow et al. 1994; Laruelle et al. 1995; Carson et al. 1997; Laruelle et al. 1997; Volkow et al. 1999). One frequent observation that has arisen from studies on the effects of changes in dopamine on radiotracer binding in rodent and primate PET studies is that the lower affinity radiotracers, such as raclopride and IBZM $\left(\mathrm{K}_{\mathrm{d}}\right.$ of 0.4-1 nM; Kung et al. 1989; Ross and Jackson 1989a), appear to be more susceptible to competition by synaptic dopamine than other $\mathrm{D}_{2}$ radiotracers such as epidepride and $\mathrm{N}$-methylspiperone, which have very high receptor affinities $\left(\mathrm{K}_{\mathrm{d}}<0.1 \mathrm{nM}\right)$.

$\mathrm{D}_{1}$ receptors have been less frequently investigated in imaging studies than $\mathrm{D}_{2}$ receptors. Most of the available radiotracers have structures based on the $D_{1}$ antagonist, SCH 23390, a benzazepine derivative with a $\mathrm{K}_{\mathrm{d}}$ of 0.1-0.3 nM (Billard et al. 1984; Andersen et al. 1985). For non-benzazepine compounds the only $\mathrm{D}_{1}$ radiotracer which has been evaluated so far is $\left[{ }^{11} \mathrm{C}\right] \mathrm{A} 69024$, which was found to be effective at labeling $D_{1}$ receptors in vivo despite a relatively low affinity for the receptor (Kassiou et al. 1995). With regard to the effect of endogenous dopamine on the in vivo binding of $\mathrm{D}_{1}$ radiotracers, the few studies performed to date have been conducted using benzazepine radiotracers such as $\mathrm{SCH}$
23390 and have indicated that the binding of these radiotracers appears to be relatively resistant to pharmacologically induced changes in dopamine levels (Inoue et al. 1991; Thibaut et al. 1996; Abi-Dargham et al. 1999; Gatley et al. 2000; Gifford et al. 2000). However, by analogy with the high-affinity $\mathrm{D}_{2}$ radiotracers, it may be expected that the susceptibility of these high-affinity benzazepine derivatives to competition with dopamine will be limited as a result of their non-reversible and flow-dependent binding kinetics.

Among the 5-HT receptors, only $5-\mathrm{HT}_{2 \mathrm{~A}}$ and $5-\mathrm{HT}_{1 \mathrm{~A}}$ receptors have been imaged with PET and SPECT. Although radiotracers against these receptors have been used in a number of studies to measure receptor densities and receptor occupancies achieved by clinical drugs, there is little information currently available on the susceptibility of radiotracers against these receptors to competition with endogenous 5-HT.

Because of the relative paucity of data on the effects of competition with endogenous transmitters on radiotracer binding to $\mathrm{D}_{1}, 5-\mathrm{HT}_{1 \mathrm{~A}}$ and $5-\mathrm{HT}_{2 \mathrm{~A}}$ compared with that collected for radiotracer binding to $\mathrm{D}_{2}$ receptors, the current study was conducted with the objective of determining whether pharmacological altered dopamine and 5-HT levels would affect radiotracer binding to these receptors. The radiotracers we evaluated in the current study were $\left[{ }^{3} \mathrm{H}\right] \mathrm{A} 69024$ for $\mathrm{D}_{1}$ receptors, $\left[{ }^{3} \mathrm{H}\right] \mathrm{N}$-methylspiperone for $5-\mathrm{HT}_{2 \mathrm{~A}}$ receptors and $\left[{ }^{3} \mathrm{H}\right]$ WAY 100635 for $5-\mathrm{HT}_{1 \mathrm{~A}}$ receptors. $\left[{ }^{3} \mathrm{H}\right]$ Raclopride binding to $\mathrm{D}_{2}$ receptors was also evaluated for comparative purposes. The radiotracers we examined were selected on the basis of the fact that they have all been previously employed in PET studies and found to be effective in labeling their respective receptors in vivo. Additionally, where possible, the radiotracer we used was one with a relatively moderate receptor affinity and reversible binding kinetics. This was because although these radiotracers give improved receptor quantitation in vivo, they also may be more susceptible to the effects of competition with the endogenous neurotransmitter.

\section{MATERIALS AND METHODS}

\section{Drugs}

4-hydroxybutyrate, d-amphetamine, p-chloroamphetamine, fenfluramine and p-chlorophenylalanine were obtained from Sigma (St. Louis, MO). Cocaine and methylenedioxymethamphetamine (MDMA) were both obtained from NIDA (Bethesda, MD). Reserpine was obtained from Research Biochemical Incorporated (Natick, MA). Paroxetine was obtained from SmithKline Beecham Pharmaceuticals. $\left[{ }^{3} \mathrm{H}\right]$ Raclopride $(78 \mathrm{Ci} /$ $\mathrm{mmol})$ and $\left[{ }^{3} \mathrm{H}\right] \mathrm{N}$-methlylspiperone $(84 \mathrm{Ci} / \mathrm{mmol})$ were obtained from Dupont New England Nuclear (Boston, MA). [ $\left.{ }^{3} \mathrm{H}\right]$ WAY $100635(82.0 \mathrm{Ci} / \mathrm{mmol})$ was 
obtained from Amersham (Arlington Heights, IL). Racemic $\left[{ }^{3} \mathrm{H}\right] \mathrm{A}-69024$ was synthesized and labeled essentially as described by Kassiou et al. (1994), with a specific activity of approximately $85 \mathrm{Ci} / \mathrm{mmol}$. The radiotracers evaluated in the current study and their receptors affinities are summarized in Table 1.

\section{In vivo Binding}

Male Swiss-Webster (25-30g) mice were purchased from Taconic Farms (Germantown, NY) and were injected via the tail vein, with $1 \mu \mathrm{Ci}$ of radiotracer in $0.9 \%$ saline. Groups of 5-7 mice were then sacrificed by cervical dislocation at various time points post-injection and the frontal cortex, hippocampus, striatum and cerebellum dissected out. Each tissue sample was weighed and dissolved in tissue solubilizer overnight. UltimaGold XR scintillation fluid was added and tissue radioactivity was determined using a Packard Model 1600 TR liquid scintillation counter.

To determine the effects of pharmacological increases or decreases in dopamine and 5-HT mice were injected intraperitoneally with drugs either prior or following the radiotracer administration. Mice treated with reserpine were warmed on a heating pad prior to the radiotracer administration in order to reduce the effects of the reserpine-induced hypothermia on radiotracer kinetics and binding.

Drugs were administered in $0.9 \%$ saline. Exceptions were $\mathrm{p}$-chlorophenylalanine which was dissolved in $40 \%$ 2-hydroxypropyl- $\beta$-cyclodextrin, and reserpine, which was dissolved in a small quantity of lactic acid, diluted with water, and administered immediately.

\section{Measurement of Tissue Levels of 5-HT}

The effect of chronic treatment with p-chlorophenylalanine on tissue levels of 5-HT was determined by ho-

Table 1. Receptor Affinities of Radiotracers Evaluated in the Current Study

\begin{tabular}{|c|c|c|}
\hline Radiotracer & $\begin{array}{l}\text { Receptor } \\
\text { Labeled }\end{array}$ & Affinity \\
\hline$\left[{ }^{3} \mathrm{H}\right]$ Raclopride & $\mathrm{D}_{2}$ & $1 \mathrm{nM}^{1,2}$ \\
\hline$\left[{ }^{3} \mathrm{H}\right] \mathrm{A} 69024$ & $\mathrm{D}_{1}$ & $\begin{array}{l}6 \mathrm{nM}^{3}-12 \mathrm{nM}^{4} \\
0.5 \mathrm{nM}\left(5-\mathrm{HT}_{2 \mathrm{~A}}\right)^{5}\end{array}$ \\
\hline$\left[{ }^{3} \mathrm{H}\right] \mathrm{N}$-methylspiperone & $5-\mathrm{HT}_{2 \mathrm{~A}}, \mathrm{D}_{2}$ & $0.1 \mathrm{nM}\left(\mathrm{D}_{2}\right)^{5}$ \\
\hline$\left[{ }^{3} \mathrm{H}\right]$ WAY 100635 & $5-\mathrm{HT}_{1 \mathrm{~A}}$ & $0.4 \mathrm{nM}^{6,7}$ \\
\hline \multicolumn{3}{|l|}{${ }^{1}$ Kohler et al. 1985} \\
\hline \multicolumn{3}{|c|}{${ }^{2}$ Ross and Jackson 1989a } \\
\hline \multicolumn{3}{|c|}{$\begin{array}{l}{ }^{3} \text { A.N. Gifford and S.J. Gatley, unpublished observations using active } \\
\text { enantiomer }\end{array}$} \\
\hline \multicolumn{3}{|l|}{$\begin{array}{l}\text { enantiomer } \\
{ }^{4} \text { Kerkman et al } 1989\end{array}$} \\
\hline \multicolumn{3}{|l|}{${ }^{5}$ Lyon et al. 1986} \\
\hline \multicolumn{3}{|l|}{${ }^{6}$ Forster et al. 1995} \\
\hline \multicolumn{3}{|l|}{${ }^{7}$ Khawaja et al. 1995} \\
\hline
\end{tabular}

mogenizing brain tissue in $0.5 \mathrm{M}$ percholoric acid containing $0.1 \%$ EDTA. The homogenate was then centrifuged and 5-HT levels in the supernatant measured using high pressure liquid chromatography (HPLC). For HPLC a C18 reverse phase column (Bioanalytical Systems Inc., IN) coupled to an electrochemical detector (Bioanalytical Sytems Inc.) was used. The mobile phase consisted of $8 \%$ acetonitrile, $1 \%$ tetrahydrofuran, $15 \mathrm{mM}$ sodium phosphate, $30 \mathrm{mM}$ sodium citrate, $0.027 \mathrm{mM}$ EDTA, $10 \mathrm{mM}$ diethylamine $\mathrm{HCl}, 2 \mathrm{mM}$ decanesulphonic acid, $\mathrm{pH}$ 4.0.

\section{Data Calculations and Statistics}

The percent-injected dose per gram of tissue (\% ID/g) was determined by dividing the tissue radioactivity per gram wet weight $(\mathrm{DPM} / \mathrm{g})$ by the total radioactivity injected into the animal. The striatum to cerebellum ratio minus one (ST/CE-1) or cortex to cerebellum ratio minus one (CO/CE-1) was calculated by dividing the DPM/g for the striatum or cortex by the DPM/g for the cerebellum. For each radioligand the brain uptake was determined over several time points and this data was then used to determine the optimal sacrifice time for each radiotracer in the in vivo competition studies. Statistical significance was determined using a 1-way analysis of variance (ANOVA), followed by a post-hoc Dunnett's test.

\section{RESULTS}

\section{$\left[{ }^{3} \mathrm{H}\right]$ Raclopride}

Time Course of Binding. The time course of $\left[{ }^{3} \mathrm{H}\right] \mathrm{raclo}-$ pride accumulation in the striatum and cerebellum was determined at various time points following its administration to the mice (Figure 1 ). $\left[{ }^{3} \mathrm{H}\right]$ raclopride showed high brain uptake in the striatum and reversible binding kinetics.

Competition Studies. The ffect of pharmacological increases in dopamine on the in vivo binding of $\left[{ }^{3} \mathrm{H}\right]$ raclopride to striatal $\mathrm{D}_{2}$ receptors was determined by giving the mice either cocaine or amphetamine five minutes prior to the administration of $\left[{ }^{3} \mathrm{H}\right]$ raclopride. Animals were sacrificed at a 30-min time point, at which time visual observations of the animals indicated that the behavioral effects of amphetamine and cocaine were just starting to decline. At this time point, analysis of the striatal and cerebellum levels of $\left[{ }^{3} \mathrm{H}\right]$ raclopride uptake indicated that the ST/CE-1 ratios were considerably reduced at the high dose of amphetamine $(10 \mathrm{mg} / \mathrm{kg}$, i.p.). However, with the lower dose amphetamine (3 $\mathrm{mg} / \mathrm{kg}$, i.p.), or with cocaine, the reduction in ST/CE-1 ratios did not reach significance (Table 2).

To produce dopamine depletion the mice were given either reserpine $(5 \mathrm{mg} / \mathrm{kg}$, i.p.) 15 hours prior to the $\left[{ }^{3} \mathrm{H}\right]$ raclopride administration or 4-hydroxybutyrate 


\section{$\left[{ }^{3} \mathrm{H}\right]$ Raclopride}

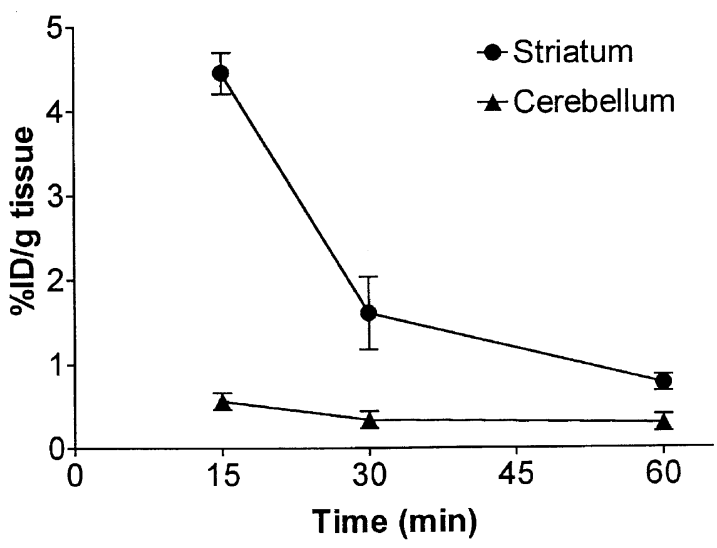

Figure 1. Time course of brain radioactivity following the intravenous administration of $\left[{ }^{3} \mathrm{H}\right]$ raclopride. Data is shown as $\%$ injected dose per gram tissue (\%ID/g tissue) and are means ( \pm S.E.M.) of 7 mice.

(400 mg/kg, i.p.) 45 minutes prior to $\left[{ }^{3} \mathrm{H}\right]$ raclopride administration. Both treatments produced a significant increase in striatal $\left[{ }^{3} \mathrm{H}\right]$ raclopride binding.

Washout Studies. In addition to examining the effect of amphetamine and 4-hydroxybutyrate when given prior to $\left[{ }^{3} \mathrm{H}\right]$ raclopride administration, experiments were also conducted to determine the effects of these two drugs when the drugs were given five minutes after $\left[{ }^{3} \mathrm{H}\right]$ raclopride administration. At this time, $\left[{ }^{3} \mathrm{H}\right]$ raclopride accu-

Table 2. In vivo Binding of $\left[{ }^{3} \mathrm{H}\right]$ Raclopride: Effect of Drugs Increasing or Decreasing Extracellular Dopamine

\begin{tabular}{|c|c|c|}
\hline & ST/CB-1 ${ }^{1}$ & $\%$ Control \\
\hline \multicolumn{3}{|l|}{ EXPERIMENT \#1 } \\
\hline Control & $5.0 \pm 0.3(7)$ & 100 \\
\hline Cocaine & & \\
\hline (10 mg/kg, i.p.) & $5.1 \pm 0.3(7)$ & 102 \\
\hline Cocaine & & \\
\hline (30 mg/kg, i.p.) & $4.3 \pm 0.3(6)$ & 86 \\
\hline Amphetamine & & \\
\hline (3 mg/kg, i.p.) & $4.4 \pm 0.4(7)$ & 88 \\
\hline $\begin{array}{l}\text { Amphetamine } \\
(10 \mathrm{mg} / \mathrm{kg} \text { i.p. })\end{array}$ & $1.8 \pm 0.4(7)^{* *}$ & 36 \\
\hline \multicolumn{3}{|l|}{ EXPERIMENT \#2 } \\
\hline Control & $4.3 \pm 0.4(7)$ & 100 \\
\hline $\begin{array}{l}\text { 4-Hydroxybutyrate } \\
\text { (400 mg/kg, i.p.) }\end{array}$ & $8.0 \pm 0.3(7)^{* *}$ & 186 \\
\hline Reserpine & & \\
\hline (5 mg/kg, i.p.) & $7.7 \pm 0.4(6)^{* *}$ & 179 \\
\hline
\end{tabular}

** $p<.01$ (Dunnett's test)

${ }^{1}$ Striatum/cerebellum ratio minus one.

Cocaine and amphetamine were given i.p. 5 min prior to radiotracer (i.v.). 4-Hydroxybutyrate and reserpine were given i.p. 45 minutes and 20 hours, respectively, prior to radiotracer (i.v.). Animals were sacrificed $30 \mathrm{~min}$ after radiotracer administration. Data are means ( \pm S.E.M.) of the number of animals indicated. Experiment \#1: $\mathrm{F}(4,29)=12.7, p<.01$. Experiment $\# 2: \mathrm{F}(2,19)=24.0, p<.01$ mulation in the striatum should already have peaked and be in the declining (or washout) phase. However, despite the reversal in the order of drug administration, similar effects of amphetamine and 4-hydroxybutyrate on the ST/CE-1 ratios were obtained. The values were as follows: control $4.3 \pm 0.4(7), 10 \mathrm{mg} / \mathrm{kg}$ amphetamine $1.9 \pm 0.2(7), 400 \mathrm{mg} / \mathrm{kg}$ 4-hydroxybutyrate $7.6 \pm 0.4(6) ;$ (values are means \pm SEM (n); ANOVA: $\mathrm{F}(2,17)=73.7$, $p<.01)$.

\section{$\left[{ }^{3} \mathrm{H}\right] \mathrm{A} 69024$}

Time Course of Binding. $\quad\left[{ }^{3} \mathrm{H}\right] \mathrm{A} 69024$ demonstrated high uptake into the striatum $(7.4 \%$ at 2 minutes $)$ and a moderately rapid clearance rate, with a striatal half-life of approximately 21 minutes (Figure 2). Despite its relatively low affinity for the $\mathrm{D}_{1}$ receptor, $\left[{ }^{3} \mathrm{H}\right] \mathrm{A} 69024$ showed a good striatum to cerebellum binding ratio. Administration of SCH 23390 (0.3 mg/kg, i.v.) together with the $\left[{ }^{3} \mathrm{H}\right] \mathrm{A} 69024$ reduced the striatal binding potential (striatum/cerebellum ratio minus 1 ) at the $30-\mathrm{min}$ time point from $4.4 \pm 0.4(\mathrm{n}=6)$ to $-0.17 \pm 0.1(\mathrm{n}=6)$, confirming that the radiotracer was binding to $D_{1}$ receptors in this region.

Competition Studies. To determine the effect of pharmacological increases in dopamine on $\left[{ }^{3} \mathrm{H}\right] \mathrm{A} 69024$, mice were given either cocaine or amphetamine five minutes prior to the radiotracer administration and sacrificed 30 minutes after the radiotracer administration. No significant decrease in striatal $\left[{ }^{3} \mathrm{H}\right] \mathrm{A} 69024$ binding was observed with the lower amphetamine dose or with cocaine (Table 3). Only the high dose amphetamine pro-

\section{$\left[{ }^{3} \mathrm{H}\right] \mathrm{A69024}$}

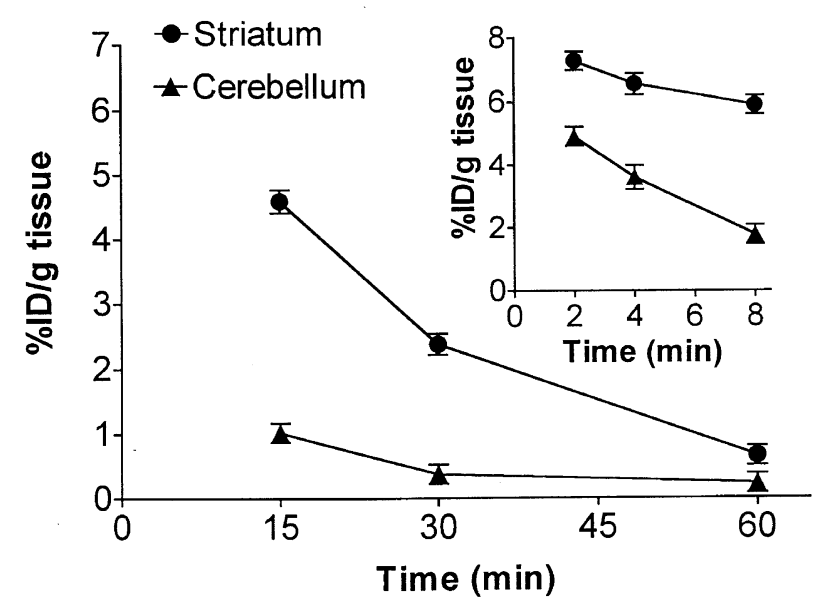

Figure 2. Time course of brain radioactivity following the intravenous administration of $\left[{ }^{3} \mathrm{H}\right] \mathrm{A} 69024$. Data shown in the inset was collected in a separate experiment and shows the brain radioactivity at short time intervals after radiotracer administration. Data points are means ( \pm S.E.M.) of 6-7 mice. 
duced a significant decrease in striatal levels of the radiotracer, although this decrease was smaller in magnitude than that observed in the $\left[{ }^{3} \mathrm{H}\right]$ raclopride experiments.

In dopamine depletion studies using 4-hydroxybutyrate, no significant increase in [3H]A69024 binding was observed by the drug treatment. Similarly, in earlier experiments with reserpine in which animals were sacrificed at a 15-min time point after radiotracer administration $\left[{ }^{3} \mathrm{H}\right] \mathrm{A} 69024$ was found to be paradoxically reduced following reserpine treatment (data not shown).

Washout Studies. As in the $\left[{ }^{3} \mathrm{H}\right]$ raclopride studies, washout experiments were conducted with $\left[{ }^{3} \mathrm{H}\right] \mathrm{A} 69024$, in which amphetamine and 4-hydroxybutyrate were given five minutes after radiotracer administration, rather than prior to the radiotracer administration as shown in Table 3. However, despite the reversal in the order of drug administration, the data obtained was similar. The ST/CE-1 ratios obtained were as follows: control $6.2 \pm$ 0.3 (7), $3 \mathrm{mg} / \mathrm{kg}$ amphetamine $6.0 \pm 0.4(6), 10 \mathrm{mg} / \mathrm{kg}$ amphetamine $4.2 \pm 0.2(7), 400 \mathrm{mg} / \mathrm{kg}$ 4-hydroxybutyrate $6.4 \pm 0.5(7)$, (data are means \pm SEM (n); ANOVA: $\mathrm{F}(3,23)=9.6, p<.01)$. Only the high dose of amphetamine produced a change in striatal binding of $\left[{ }^{3} \mathrm{H}\right] \mathrm{A} 69024$ which reached significance, as observed in the competition studies.

\section{$\left[{ }^{3} \mathrm{H}\right] \mathrm{N}-M e t h y l s p i p e r o n e$}

Time Course of Binding. The time course of $\left[{ }^{3} \mathrm{H}\right] \mathrm{N}-$ methylspiperone binding was examined in the striatum, occipital cortex and cerebellum (Figure 3). Great-

Table 3. In vivo Binding of $\left[{ }^{3} \mathrm{H}\right] \mathrm{A} 69024$ : Effect of Drugs Increasing or Decreasing Extracellular Dopamine

\begin{tabular}{|c|c|c|}
\hline & ST/CB-1 ${ }^{1}$ & $\%$ Control \\
\hline \multicolumn{3}{|l|}{ EXPERIMENT \#1 } \\
\hline Control & $5.9 \pm 0.4(5)$ & 100 \\
\hline \multicolumn{3}{|l|}{ Cocaine } \\
\hline (10 mg/kg, i.p.) & $5.4 \pm 0.1(7)$ & 92 \\
\hline \multicolumn{3}{|l|}{ Cocaine } \\
\hline (30 mg/kg, i.p.) & $6.2 \pm 0.3(6)$ & 105 \\
\hline \multicolumn{3}{|l|}{ Amphetamine } \\
\hline (3 mg/kg, i.p.) & $5.3 \pm 0.3(6)$ & 90 \\
\hline \multicolumn{3}{|l|}{ Amphetamine } \\
\hline (10mg/kg, i.p.) & $4.2 \pm 0.6(6)^{*}$ & 71 \\
\hline \multicolumn{3}{|l|}{ EXPERIMENT \#2 } \\
\hline Control & $6.2 \pm 0.3(7)$ & 100 \\
\hline $\begin{array}{l}\text { 4-Hydroxybutyrate } \\
\text { (400 mg/kg, i.p.) }\end{array}$ & $5.9 \pm 0.4(7)$ & 95 \\
\hline \multicolumn{3}{|c|}{$\begin{array}{l}\text { }{ }^{1} \text { Striatum/cerebellum ratio minus one. } \\
\text { Cocaine and amphetamine were given i.p. } 5 \text { minutes prior to ra- } \\
\text { diotracer (i.v.). 4-Hydroxybutyrate was given i.p. } 45 \text { minutes prior to ra- } \\
\text { diotracer (i.v.). Animals were sacrificed } 30 \text { minutes after radiotracer ad- } \\
\text { ministration. Data are means }( \pm \text { S.E.M.) of the number of animals } \\
\text { indicated. Experiment } \# 1: \mathrm{F}(4,25)=3.7, p<.05 \text {. Experiment } \# 2: \mathrm{t}_{(12)} \\
0.65 \text {, not significant (t-test). }\end{array}$} \\
\hline
\end{tabular}

est uptake of this tracer was observed in the striatum, reflecting the high affinity of this tracer for $D_{2}$ dopamine receptors. The washout of radiotracer from this region was slow, with only a $5 \%$ decline in radiotracer levels from 60 to 240 minutes after radiotracer administration. In contrast to its uptake in the striatum, in the occipital cortex the levels of uptake were smaller and the washout of radiotracer was much faster. Since $D_{2}$ receptors are largely absent from the occipital cortex the $\left[{ }^{3} \mathrm{H}\right] \mathrm{N}$-methylspiperone binding in this region will mostly represent binding to $5-\mathrm{HT}_{2 \mathrm{~A}}$ receptors. Lowest levels of radiotracer binding were obtained in the cerebellum, reflecting the low levels of these receptors in this region.

Competition Studies. The susceptibility of cortical $\left[{ }^{3} \mathrm{H}\right] \mathrm{N}-$ methylspiperone binding to competition with endogenous 5-HT was examined using the 5-HT releasing agents, fenfluramine and p-chloroamphetamine (Table 4). In the first series of experiments the effects of fenfluramine on $\left[{ }^{3} \mathrm{H}\right] \mathrm{N}$-methylspiperone binding was examined. Fenfluramine produced a dose-dependent reduction in cortical NMS binding, with a greater than $50 \%$ reduction in the cortical binding at the highest fenfluramine dose. In order to determine if the fenfluramineinduced decreases in 5-HT binding were a consequence of 5-HT release, experiments were conducted in which the fenfluramine was co-administered with the 5-HT uptake blocker, paroxetine. In microdialysis and brain slice experiments, uptake inhibitors such as paroxetine, which by themselves produce only minor effects on extracellular 5-HT, have been consistently found to prevent the much larger levels of 5-HT release produced by releasing agents such as fenfluramine (Raiteri et al. 1995; Gobbi et al. 1998). In the $\left[{ }^{3} \mathrm{H}\right] \mathrm{N}$-methylspiperone experiments, paroxetine itself produced only a slight decrease in

\section{$\left[{ }^{3} \mathrm{H}\right] \mathrm{N}-$-methylspiperone}

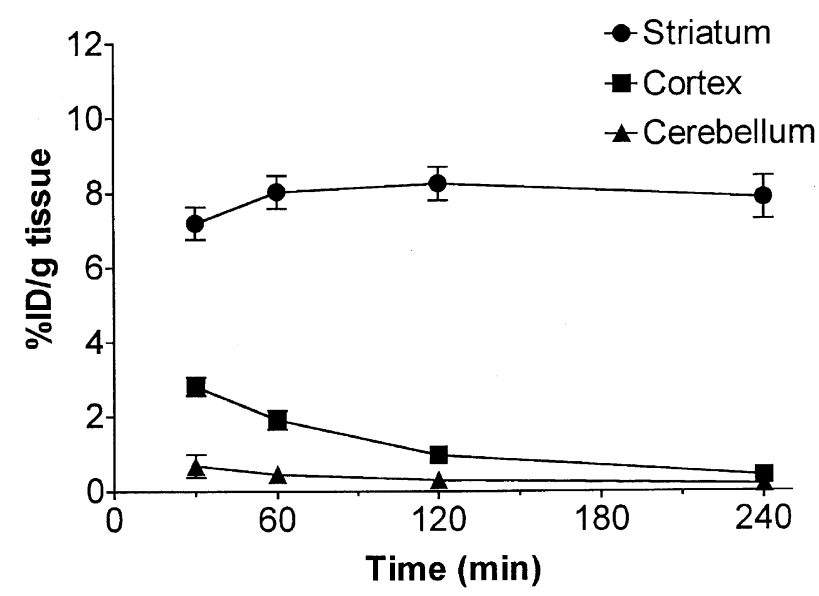

Figure 3. Time course of brain radioactivity following the intravenous administration of $\left[{ }^{3} \mathrm{H}\right] \mathrm{N}$-methylspiperone. Data points are means ( \pm S.E.M.) of 5-6 mice. 
$\left[{ }^{3} \mathrm{H}\right] \mathrm{N}$-methylspiperone binding which did not reach statistical significance. However, in contrast to the results predicted from the microdialysis data, when fenfluramine was given in combination with paroxetine, the fenfluramine-induced decrease in $\left[{ }^{3} \mathrm{H}\right] \mathrm{N}$-methylspiperone binding appeared to be enhanced rather than reduced by the paroxetine. This suggests that mechanisms other than 5-HT release may have been responsible for the fenfluramine-induced reduction in $\left[{ }^{3} \mathrm{H}\right] \mathrm{N}$-methylspiperone binding in vivo.

In a second series of experiments the effect of p-chloroamphetamine on cortical NMS binding was evaluated. However, in contrast to the effects of fenfluramine on $\left[{ }^{3} \mathrm{H}\right] \mathrm{N}$-methylspiperone binding, p-chloroamphetamine did not alter $\left[{ }^{3} \mathrm{H}\right] \mathrm{N}$-methylspiperone binding at any of the doses examined.

\section{$\left[{ }^{3} \mathrm{H}\right]$ WAY 100635}

Time Course of Binding. $\quad\left[{ }^{3} \mathrm{H}\right] \mathrm{WAY} 100635$ binding showed high uptake in the hippocampus and frontal cortex, regions with high densities of 5-HT1A receptors, and lower uptake in the striatum and cerebellum, in which 5-HT1A receptors are largely absent (Figure 4). Optimal hippocampal to cerebellum and cortex to cerebellum ratios were obtained at a 60 -min sacrifice time point.

Competition Studies. Competition of cortical and hippocampal $\left[{ }^{3} \mathrm{H}\right]$ WAY 100635 binding with endogenous

Table 4. In vivo Binding of $\left[{ }^{3} \mathrm{H}\right] \mathrm{N}-$ methylspiperone: Effect of Drugs Increasing Extracellular 5-HT

\begin{tabular}{|c|c|c|}
\hline & $\mathrm{CO} / \mathrm{CB}-1^{1}$ & $\%$ Control \\
\hline \multicolumn{3}{|l|}{ EXPERIMENT \#1 } \\
\hline Control & $2.5 \pm 0.2(7)$ & 100 \\
\hline Paroxetine $(0.5 \mathrm{mg} / \mathrm{kg})$ & $2.3 \pm 0.3(6)$ & 93 \\
\hline Paroxetine $(2.0 \mathrm{mg} / \mathrm{kg})$ & $2.0 \pm 0.2(7)$ & 80 \\
\hline Fenfluramine $(10 \mathrm{mg} / \mathrm{kg})$ & $1.6 \pm 0.3(6)^{* *}$ & 62 \\
\hline \multicolumn{3}{|l|}{ Paroxetine $(0.5 \mathrm{mg} / \mathrm{kg})+$} \\
\hline $\begin{array}{l}\text { Paroxetine }(2.0 \mathrm{mg} / \mathrm{kg})+ \\
\quad \text { fenfluramine }(10 \mathrm{mg} / \mathrm{kg})\end{array}$ & $1.1 \pm 0.1(6)^{* *}$ & 44 \\
\hline \multicolumn{3}{|l|}{ EXPERIMENT \#2 } \\
\hline $\begin{array}{l}\text { Control } \\
\text { p-Chloroamphetamine }\end{array}$ & $1.9 \pm 0.1(10)$ & 100 \\
\hline$(1 \mathrm{mg} / \mathrm{kg})$ & $2.1 \pm 0.1(8)$ & 110 \\
\hline \multicolumn{3}{|l|}{ p-Chloroamphetamine } \\
\hline \multicolumn{2}{|l|}{ p-Chloroamphetamine } & 94 \\
\hline \multicolumn{3}{|l|}{${ }^{* *} p<.01$ (Dunnett's test) } \\
\hline \multicolumn{3}{|c|}{${ }^{1}$ Cortex/cerebellum ratio minus one. } \\
\hline $\begin{array}{l}\text { Paroxetine, fenfluramine and p-ch } \\
\text { minutes prior to radiotracer (i.v.). Mi } \\
\text { radiotracer administration. Experime } \\
\text { different batches of }\left[{ }^{3} \mathrm{H}\right] \mathrm{N}-\text { methylspip } \\
\text { control values. Data are means }( \pm \mathrm{S} . \\
\text { cated. Experiment } \# 1 \text { : } \mathrm{F}(5,32)=7.3 \text {, } \\
\text { 1.03, not significant. }\end{array}$ & $\begin{array}{l}\text { roamphetamine } \\
\text { were sacrificed } 6 \\
\mathrm{~s} \# 1 \text { and } \# 2 \text { were } \mathrm{c} \\
\text { rone which gave } \mathrm{s} \\
\text { 4.) of the number } \\
<0.01 \text {. Experimer }\end{array}$ & $\begin{array}{l}\text { e given i.p. } 5 \\
\text { ain following } \\
\text { ducted using } \\
\text { htly different } \\
\text { animals indi- } \\
\text { \$2: } \mathrm{F}(3,30)=\end{array}$ \\
\hline
\end{tabular}

5-HT was determined using three different releasing agents, p-chloroamphetamine, fenfluramine and methylenedioxymethamphetamine (Table 5). None of these agents produced a decrease in [ ${ }^{3} \mathrm{H}$ ]WAY 100635 binding which reached statistical significance. The 5-HT and dopamine uptake blocker, cocaine, also did not produce a significant change in cortical or hippocampal $\left[{ }^{3} \mathrm{H}\right]$ WAY 100635 binding.

In a second series of experiments the effects of 5-HT depletion by the 5-HT synthesis inhibitor, p-chlorophenylalanine, was examined. Treatment of the mice with p-chlorophenylalanine $(150 \mathrm{mg} / \mathrm{kg}$ i.p. twice per day for four days) reduced tissue 5-HT levels in the cortex by $57 \%$ (control mice $148 \pm 19 \mathrm{ng} / \mathrm{g}(\mathrm{n}=5$ ); p-chlorophenylalanine mice $63 \pm 11 \mathrm{ng} / \mathrm{g}(\mathrm{n}=5))$ and in the hippocampus by $62 \%$ (control mice $48 \pm 11 \mathrm{ng} / \mathrm{g}(\mathrm{n}=$ 4); p-chlorophenylalanine mice $18 \pm 1 \mathrm{ng} / \mathrm{g}(\mathrm{n}=4)$ ). However, despite the depletion of tissue 5-HT, there was no indication of an increase in the in vivo cortical or hippocampal $\left[{ }^{3} \mathrm{H}\right]$ WAY 100635 binding (Table 5). Rather, the binding appeared to be slightly reduced, although not reaching the level of significance.

\section{DISCUSSION}

The degree to which radiotracer binding to a particular G-protein coupled receptor will be sensitive to competition with endogenous transmitters will depend on a number of factors, some of which are related to properties of the receptors and some to the properties of the radioligand (recently reviewed by Laruelle 2000). For receptor factors, an essential requirement for being able to observe competition is that a significant fraction of the receptor should be (or become) occupied by the

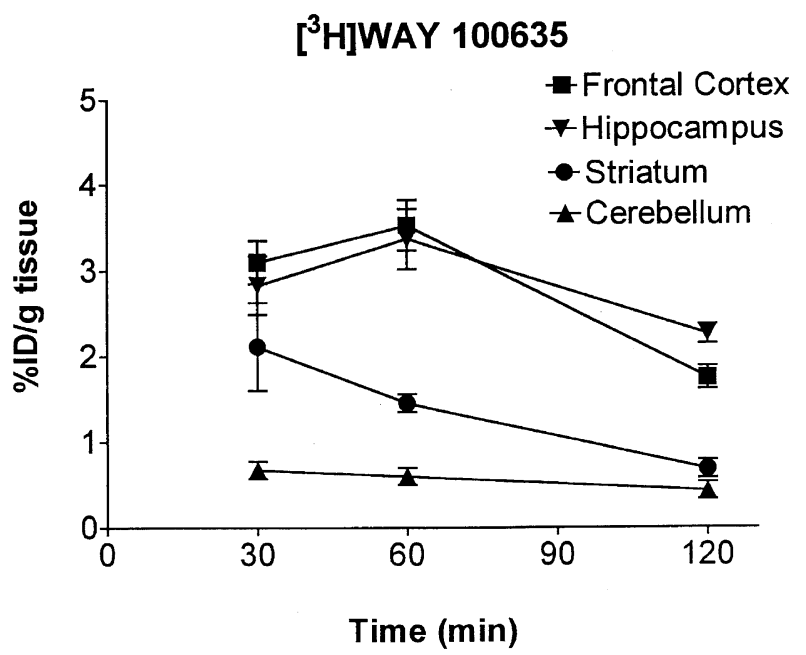

Figure 4. Time course of brain radioactivity following the intravenous administration of $\left[{ }^{3} \mathrm{H}\right]$ WAY 100635 . Data points are means ( \pm S.E.M.) of 7-8 mice. 
Table 5. In vivo Binding of [ $\left.{ }^{3} \mathrm{H}\right]$ WAY100635: Effect of Drugs Increasing or Depleting 5-HT

\begin{tabular}{|c|c|c|c|c|}
\hline & $\mathrm{CO} / \mathrm{CB}-1^{1}$ & $\%$ Control & $\mathrm{HP} / \mathrm{CB}-1^{2}$ & $\%$ Control \\
\hline \multicolumn{5}{|l|}{ EXPERIMENT \#1 } \\
\hline Control & $4.3 \pm 0.3(10)$ & 100 & $4.1 \pm 0.3(10)$ & 100 \\
\hline $\begin{array}{l}\text { p-Chloroamphetamine } \\
(1 \mathrm{mg} / \mathrm{kg})\end{array}$ & $5.0+0.3(11)$ & 116 & $4.6+0.4(11)$ & 112 \\
\hline p-Chloroamphetamine & & & $4.0-0.4$ (11) & 112 \\
\hline$(3 \mathrm{mg} / \mathrm{kg})$ & $5.0 \pm 0.4(16)$ & 116 & $4.8 \pm 0.4(16)$ & 117 \\
\hline $\begin{array}{l}\text { p-Chloroamphetamine } \\
(10 \mathrm{mg} / \mathrm{kg})\end{array}$ & $4.1 \pm 0.3(9)$ & 95 & $4.2 \pm 0.4(9)$ & 102 \\
\hline Fenfluramine & & & & \\
\hline$(3 \mathrm{mg} / \mathrm{kg})$ & $4.0 \pm 0.4(11)$ & 93 & $3.4 \pm 0.4(11)$ & 83 \\
\hline MDMA $(10 \mathrm{mg} / \mathrm{kg})$ & $4.5 \pm 0.3(11)$ & 105 & $4.7 \pm 0.3(11)$ & 115 \\
\hline Cocaine $(20 \mathrm{mg} / \mathrm{kg})$ & $4.5 \pm 0.3(11)$ & 107 & $4.6 \pm 0.4(10)$ & 112 \\
\hline \multicolumn{5}{|l|}{ Experiment 2} \\
\hline $\begin{array}{l}\text { Control } \\
\text { p-Chlorophenylalanine }\end{array}$ & $3.8 \pm 0.4(11)$ & 100 & $5.0 \pm 0.7(11)$ & 100 \\
\hline (150 mg/kg x2/day for 4 days) & $3.3 \pm 0.2(11)$ & 87 & $4.2 \pm 0.3(11)$ & 84 \\
\hline
\end{tabular}

${ }^{1}$ Cortex/cerebellum ratio minus one.

${ }^{2}$ Hippocampus/cerebellum ratio minus one

p-Chloroamphetamine, fenfluramine, MDMA and cocaine were given i.p. 5 min prior to radiotracer (i.v.). For p-chlorophenylalanine the final injection was given $24 \mathrm{~h}$ prior to radiotracer. Animals were sacrificed $45 \mathrm{~min}$ following radiotracer administration (i.v.). Data are means ( \pm S.E.M.) of the number of animals indicated. Experiment \#1: Cortex: $F(6,71)=1.6$, not significant, hippocampus: $F(6,71)=1.5$, not significant. Experiment \#2: Cortex $\mathrm{t}_{(20)}=1.1$, not significant, hippocampus $\mathrm{t}_{(20)}=1.1$, not significant.

transmitter. The greatest sensitivity to increases or decreases in transmitter levels will be obtained if the basal occupancy of the receptor by the transmitter is normally fairly high. Thus if the basal occupancy is normally about $50 \%$, a complete depletion of the endogenous transmitter could potentially produce a 2 -fold increase in the amount of specific radiotracer binding, while a doubling of the endogenous transmitter levels would produce a $34 \%$ decrease in radiotracer binding. However, if the basal occupancy of the receptor by the endogenous transmitter is only, say, $10 \%$, then a complete depletion of the endogenous transmitter would produce a $11 \%$ increase in radiotracer binding to receptors, while a doubling of the endogenous transmitter levels would produce only a $9 \%$ fall in radiotracer binding. For a particular receptor a low basal level of occupancy of the receptors by the transmitter will occur if one or more of the following conditions apply: (1) the average synaptic cleft concentration of the transmitter is low; (2) the receptor has a low affinity for the transmitter and/or the receptors are mostly in a low agonist affinity state; (3) the receptors are inaccessible to the transmitter, either as a result of being located at predominantly extrasynaptic rather than synaptic sites or because they are predominantly internalized inside the cell rather than being located on the plasma-membrane.

In addition to receptor factors, the characteristics of the radioligand also can have an effect on susceptibility to competition with endogenous transmitters. Pharmacological interventions which significantly change brain neurotransmitters may in some cases have an effect on cerebral blood flow and/or peripheral radiotracer me- tabolism and this can in turn alter the brain uptake of the radiotracer and hence obscure the effects of receptorcompetition. In the case of the effects on cerebral blood flow, radiotracers which have very high affinities for their receptor are in general more sensitive to changes in this parameter than lower affinity radiotracers. This is especially the case in situations where the receptor density in the tissue is high, as is the situation for $D_{1}$ and $D_{2}$ receptors in the striatum for example. In such receptorrich brain regions high affinity radiotracers tend to accumulate in a non-reversible manner and consequently fail to approach a situation, at least within the time course of the experiment, in which equilibrium binding conditions exist (Gifford et al. 1998). As a result their total accumulation in the target region will depend strongly on their rate of delivery via the blood stream, in addition to the receptor availability in this region.

In the present study competition between endogenous dopamine and radiotracer binding to $\mathrm{D}_{2}$ dopamine receptors was determined using $\left[{ }^{3} \mathrm{H}\right]$ raclopride. In the dopamine depletion experiments an approximately $80 \%$ increase in $\left[{ }^{3} \mathrm{H}\right]$ raclopride binding to striatal $\mathrm{D}_{2}$ receptors was observed after treatment of the mice with reserpine or 4-hydroxybutyrate. This degree of increase in raclopride binding after dopamine depletion was similar to that observed in previous studies and suggests that the basal occupancy of these receptors by dopamine is normally fairly high (Ross and Jackson 1989a; Ross 1991; Young et al. 1991). If it is assumed that these treatments produce a nearly complete reduction in dopamine levels and that the changes in specific $\left[{ }^{3} \mathrm{H}\right]$ raclopride binding in vivo faithfully follow changes in receptor availability. 
then the $80 \%$ increase in $\left[{ }^{3} \mathrm{H}\right]$ raclopride binding will correspond to a $44 \%$ occupancy of these receptors by dopamine under basal conditions. In the dopamine enhancement experiments in the present study, increases in dopamine by amphetamine administration produced decreases in $\left[{ }^{3} \mathrm{H}\right]$ raclopride binding, although only the highdose amphetamine produced decreases which reached significance. The $64 \%$ decrease in $\left[{ }^{3} \mathrm{H}\right]$ raclopride binding by the $10 \mathrm{mg} / \mathrm{kg}$ dose of amphetamine observed in the present study is similar to or slightly greater that in observed in other studies in rodents using this radiotracer (Ross and Jackson 1989a,b; Ross 1991; Young et al. 1991).

Whereas $10 \mathrm{mg} / \mathrm{kg}$ amphetamine produced a $64 \%$ decrease in $\left[{ }^{3} \mathrm{H}\right]$ raclopride binding, $20 \mathrm{mg} / \mathrm{kg}$ cocaine produced only a small decrease in $\left[{ }^{3} \mathrm{H}\right]$ raclopride binding which did not reach the level of significance. This may reflect that fact that the increase in dopamine levels produced by uptake inhibitors such as cocaine is less than that produced by amphetamine. Thus in microdialysis experiments cocaine at a dose of $20 \mathrm{mg} / \mathrm{kg}$ will produce increases in dopamine of about 5-fold (Kuczenski and Segal 1992; Morgan et al. 1997) which is about 10 times smaller than that produced by a $10 \mathrm{mg}$ / $\mathrm{kg}$ dose of amphetamine (Kuczenski and Segal 1992).

The $\mathrm{D}_{1}$ experiments in the present study were conducted using the non-benzazepine radioligand, $\left[{ }^{3} \mathrm{H}\right] \mathrm{A} 69024$. In contrast to the non-reversible binding kinetics in the striatum observed with $\mathrm{D}_{1}$ radiotracers such as SCH 23390 and NNC 756 (Halldin et al. 1986; Farde et al. 1987; Halldin et al. 1993), [ $\left.{ }^{3} \mathrm{H}\right] \mathrm{A} 69024$ had a relatively rapid washout from the striatum, which is consistent with its lower affinity for $D_{1}$ receptors. This reversible binding profile suggests that A69024 may prove to be a preferable radiotracer over the currently used high affinity benzazepine radioligands for PET studies involving quantification of $\mathrm{D}_{1}$ receptor densities. In the present study, despite its favorable binding kinetics for observing competition with endogenous dopamine, $\left[{ }^{3} \mathrm{H}\right] \mathrm{A} 69024$ appeared to be less sensitive to pharmacological changes in dopamine levels than $\left[{ }^{3} \mathrm{H}\right]$ raclopride. $\left[{ }^{3} \mathrm{H}\right] \mathrm{A} 69024$ showed smaller decreases in binding to amphetamine-induced increases in dopamine levels and in the dopamine depletion experiments $\left[{ }^{3} \mathrm{H}\right] \mathrm{A} 69024$ binding was either unchanged or changed in a direction which was opposite to that expected from competition with endogenous dopamine. These experiments hence suggest that, in contrast to $D_{2}$ receptors, the occupancy of $D_{1}$ receptors by dopamine under basal conditions may be relatively low. Previous studies examining the sensitivity of $D_{1}$ radiotracers to endogenous dopamine have been conducted using either SCH 23390 or NNC 756 and have given results which also indicate an insensitivity of $\mathrm{D}_{1}$ radiotracer binding to synaptic dopamine (Inoue et al. 1991; Thibaut et al. 1996; Abi-Dargham et al. 1999; Gatley et al. 2000; Gifford et al. 2000).
For both the $\left[{ }^{3} \mathrm{H}\right]$ raclopride experiments and the $\left[{ }^{3} \mathrm{H}\right] \mathrm{A} 69024$ experiments the animals were sacrificed at a 30-min time point after radiotracer administration. This time point was chosen so as to allowing a reasonable length of time for the drug-altered synaptic dopamine levels to affect the striatal radiotracer levels while still obtaining good striatum/cerebellum ratios for the radiotracer binding. This reasoning was based on the assumption that the elevated synaptic dopamine levels may perhaps have a greater effect on the rate of washout of the radiotracer from receptor-rich brain regions than they do on the peak brain uptake in these regions (Gatley et al. 2000).

Competition between 5- $\mathrm{HT}$ and $5-\mathrm{HT}_{2 \mathrm{~A}}$ receptors in the present study was determined using $\left[{ }^{3} \mathrm{H}\right] \mathrm{N}$-methylspiperone. Although in PET studies N-methylspiperone has most often been used to measure $\mathrm{D}_{2}$ receptors in the striatum it has also been employed to measure $5-\mathrm{HT}_{2 \mathrm{~A}}$ receptors in the cortex (Frost et al. 1987; Swart et al. 1990; Nyberg et al. 1993; Wang et al. 1995). Its affinity for $5-\mathrm{HT}_{2 \mathrm{~A}}$ receptors is slightly less than its affinity for $\mathrm{D}_{2}$ receptors but since the density of 5- $\mathrm{HT}_{2 \mathrm{~A}}$ receptors in the occipital cortex is about two orders of magnitude greater than that of $\mathrm{D}_{2}$ receptors the binding of $\left[{ }^{3} \mathrm{H}\right] \mathrm{N}-$ methylspiperone in this region will mostly be to the latter receptors. In the present study $\left[{ }^{3} \mathrm{H}\right] \mathrm{N}$-methylspiperone showed high levels of uptake in the striatum and lower levels in the cortex. The lower level of uptake into the cortex is consistent with its lower affinity for $5-\mathrm{HT}_{2 \mathrm{~A}}$ receptors compared to $\mathrm{D}_{2}$ receptors combined with the lower $5-\mathrm{HT}_{2 \mathrm{~A}}$ receptor density in this region. Although these factors will reduce the cortical $\left[{ }^{3} \mathrm{H}\right] \mathrm{N}$-methylspiperone binding relative to that in the striatum they will also result in the $\left[{ }^{3} \mathrm{H}\right] \mathrm{N}$-methylspiperone having more reversible binding kinetics in the former region, thus making it potentially sensitive to endogenous 5-HT levels. In the present study fenfluramine did reduce the levels of $\left[{ }^{3} \mathrm{H}\right] \mathrm{N}$-methylspiperone binding but this effect was not reversed by pretreating the mice with the uptake blocker, paroxetine. The most likely explanation for the effect of fenfluramine is thus a direct action of the fenfluramine or a metabolite on the $5-\mathrm{HT}_{2 \mathrm{~A}}$ receptors rather than competition with endogenous 5 -HT. This explanation is supported by receptor binding experiments. Fenfluramine is metabolized in vivo to norfenfluramine, which has an affinity for $5-\mathrm{HT}_{2 \mathrm{~A}}$ receptors of $0.3 \mu \mathrm{M}$ (Mennini et al. 1991). This concentration is similar to the potency with which both fenfluramine and norfenfluramine produce 5-HT release in in vitro experiments in synaptosomes (Gobbi et al. 1998) suggesting that norfenfluramine will occupy a significant fraction of $5-\mathrm{HT}_{2 \mathrm{~A}}$ receptors at these concentrations. In addition to the experiments with fenfluramine further evidence that $\left[{ }^{3} \mathrm{H}\right] \mathrm{N}$-methylspiperone was insensitive to manipulation of 5-HT levels was provided by the experiments with $\mathrm{p}$-choroamphetamine. Although this 
compound releases 5-HT with a potency which is about twice that of fenfluramine (Crespi et al. 1997), in the present study it did not affect the in vivo $\left[{ }^{3} \mathrm{H}\right] \mathrm{N}$-methylspiperone binding.

Similar to the data obtained with $\left[{ }^{3} \mathrm{H}\right] \mathrm{N}$-methylspiperone, the binding of $\left[{ }^{3} \mathrm{H}\right]$ WAY 100635 to $5-\mathrm{HT}_{1 \mathrm{~A}}$ receptors in the present study was also found to be insensitive to 5-HT releasing agents. To date, WAY 100635 and its analogues have been the most used radiotracers for in vivo labeling of 5- $\mathrm{HT}_{1 \mathrm{~A}}$ receptors (Pike et al. 1996; Farde et al. 1997; Carson et al. 2000). [ $\left.{ }^{3} \mathrm{H}\right]$ WAY 100635 has a moderate affinity for $5-\mathrm{HT}_{1 \mathrm{~A}}$ and in the present study showed partial reversibility in its binding kinetics to receptors in the frontal cortex and hippocampus. Competition of WAY 100635 or its analogues with endogenous 5-HT has been briefly examined in two previous studies (Ginovart et al. 2000; Plenevaux et al. 2000). Both these previous studies used 5-HT uptake inhibitors rather than releasing agents to increase 5-HT levels, despite the fact that microdialysis studies have indicated that the increase in 5-HT levels produced by uptake inhibitors in vivo is much smaller than that produced by releasing agents. In neither of these studies were these compounds found to have a significant effect on radiotracer binding, supporting the data obtained in the present study.

[ ${ }^{3} \mathrm{H}$ ]WAY 100635 binding was not found to be significantly increased by depletion of tissue levels of 5-HT produced by a 4-day treatment with the 5 -HT synthesis inhibitor, p-chlorophenylalanine. This data indicates that in addition to being insensitive to increases in 5-HT, $\left[{ }^{3} \mathrm{H}\right]$ WAY 100635 binding is also insensitive to decreases in the level of this transmitter. It should be noted, however, that although the tissue levels of 5-HT were decreased by more than $50 \%$ by the p-chlorophenylalanine treatment it is possible that the extracellular 5-HT levels may have changed by a lesser amount.

In conclusion, the data indicate that of two dopamine radiotracers examined in the present study, $\left[{ }^{3} \mathrm{H}\right]$ raclopride binding to striatal $\mathrm{D}_{2}$ receptors has the greatest sensitivity to changes in the levels of the endogenous neurotransmitter. Although $\left[{ }^{3} \mathrm{H}\right] \mathrm{A} 69024$ binding to $D_{1}$ receptors was influenced by pharmacologically-evoked increases in dopamine levels the changes were smaller than that of $\left[{ }^{3} \mathrm{H}\right]$ raclopride and, unlike $\left[{ }^{3} \mathrm{H}\right]$ raclopride, it was not sensitive to depletions in dopamine levels. For the 5-HT radiotracers neither $\left[{ }^{3} \mathrm{H}\right] \mathrm{N}$-methylspiperone binding to cortical $5-\mathrm{HT}_{2 \mathrm{~A}}$ receptors or $\left[{ }^{3} \mathrm{H}\right]$ WAY 100635 binding to cortical or hippocampal 5- $\mathrm{HT}_{1 \mathrm{~A}}$ receptors showed clear evidence of being influenced by pharmacological-evoked 5-HT release. The apparent insensitivity of these latter two ligands to relatively large increases in extracellular 5-HT will make it easier to interpret the results of receptor quantification and measurement of drug occupancies in PET studies with these radiotracers.

\section{ACKNOWLEDGMENTS}

Supported by National Institute of Health grant R01DA/ NS11552-01. This research was performed at the Brookhaven National Laboratory under contract DE-AC02-98CH10886 with the U.S. Department of Energy and supported by the Office of Health and Environmental Research.

\section{REFERENCES}

Abi-Dargham A, Simpson N, Kegeles L, Parsey R, Hwang DR, Anjilvel S, Zea-Ponce Y, Lombardo I, van Heertum R, Mann JJ, Foged C, Halldin C, Laruelle M (1999): PET studies of binding competition between endogenous dopamine and the D1 radiotracer [11C]NNC 756. Synapse 32:93-109

Andersen PH, Gronvald FC, Jansen JA (1985): A comparison between dopamine-stimulated adenylate cyclase and $3 \mathrm{H}-$ SCH 23390 binding in rat striatum. Life Sci 37:1971-83

Billard W, Ruperto V, Crosby G, Iorio LC, Barnett A (1984): Characterization of the binding of 3H-SCH 23390, a selective D-1 receptor antagonist ligand, in rat striatum. Life Sci 35:1885-93

Carson RE, Breier A, de Bartolomeis A, Saunders RC, Su TP, Schmall B, Der MG, Pickar D, Eckelman WC (1997): Quantification of amphetamine-induced changes in [11C]raclopride binding with continuous infusion. J Cereb Blood Flow Metab 17:437-447

Carson RE, Lang L, Watabe H, Der MG, Adams HR, Jagoda E, Herscovitch P, Eckelman WC (2000): PET evaluation of [(18)F]FCWAY, an analog of the 5-HT(1A) receptor antagonist, WAY-100635. Nucl Med Biol 27:493-497

Crespi D, Mennini T, Gobbi M (1997): Carrier-dependent and $\mathrm{Ca}(2+)$-dependent 5-HT and dopamine release induced by (+)-amphetamine, 3,4-methylendioxymethamphetamine, $\mathrm{p}$-chloroamphetamine and (+)-fenfluramine. Br J Pharmacol 121:1735-43

Farde L, Ginovart N, Ito H, Lundkvist C, Pike VW, McCarron JA, Halldin C (1997): PET-characterization of [carbonyl-11C]WAY-100635 binding to 5-HT1A receptors in the primate brain. Psychopharmacology 133:196-202

Farde L, Halldin C, Stone-Elander S, Sedvall G (1987): PET analysis of human dopamine receptor subtypes using 11C-SCH 23390 and 11C-raclopride. Psychopharmacology 92:278-284

Forster EA, Cliffe IA, Bill DJ, Dover GM, Jones D, Reilly Y, Fletcher A (1995): A pharmacological profile of the selective silent 5-HT1A receptor antagonist, WAY100635. Eur J Pharmacol 281:81-88

Frost JJ, Smith AC, Kuhar MJ, Dannals RF, Wagner Jr HN (1987): In vivo binding of 3H-N-methylspiperone to dopamine and serotonin receptors. Life Sci 40:987-995

Gatley SJ, Gifford AN, Carroll FI, Volkow ND (2000): Sensitivity of binding of high-affinity dopamine receptor radioligands to increased synaptic dopamine. Synapse 38:483-488

Gifford AN, Gatley SJ, Volkow ND (1998): Evaluation of the importance of rebinding to receptors in slowing the approach to equilibrium of high-affinity PET and SPECT radiotracers. Synapse 28:167-175 
Gifford AN, Park MH, Kash TL, Herman LM, Park E-H, Gatley SJ, Volkow ND (2000): Effect of amphetamineinduced dopamine release on radiotracer binding to D1 and D2 receptors in rat brain striatal slices. NaunynSchmiedeberg's Arch Pharmacol 362:413-418

Ginovart N, Hassoun W, Le Bars D, Weissmann D, Leviel V (2000): In vivo characterization of p-[(18)F]MPPF, a fluoro analog of WAY-100635 for visualization of 5-HT(1a) receptors. Synapse 35:192-200

Gobbi M, Parazzoli A, Mennini T (1998): In vitro studies on the mechanism by which $(+)$-norfenfluramine induces serotonin and dopamine release from the vesicular storage pool. Naunyn-Schmiedeberg's Arch Pharmacol 358: 323-327

Halldin C, Foged C, Farde L, Karlsson P, Hansen K, Gronvald F, Swahn CG, Hall H, Sedvall G (1993): [11C]NNC 687 and [11C]NNC 756, dopamine D-1 receptor ligands. Preparation, autoradiography and PET investigation in monkey. Nucl Med Biol 20:945-953

Halldin C, Stone-Elander S, Farde L, Ehrin E, Fasth KJ, Langstrom B, Sedvall G. (1986): Preparation of 11C-labelled SCH 23390 for the in vivo study of dopamine D-1 receptors using positron emission tomography. Int J Rad Appl Instrum [A] 37:1039-1043

Innis RB, Malison RT, al-Tikriti M, Hoffer PB, Sybirska EH, Seibyl JP, Zoghbi SS, Baldwin RM, Laruelle M, Smith EO, et al. (1992): Amphetamine-stimulated dopamine release competes in vivo for [123I]IBZM binding to the D2 receptor in nonhuman primates. Synapse 10:177-184

Inoue $\mathrm{O}$, Tsukada $\mathrm{H}$, Yonezawa $\mathrm{H}$, Suhara $\mathrm{T}$, Langstrom $\mathrm{B}$ (1991): Reserpine-induced reduction of in vivo binding of SCH 23390 and N-methylspiperone and its reversal by d-amphetamine. Eur J Pharmacol 197:143-149

Kassiou M, Mathews WB, Musachio JL, Ravert HT, Lambrecht RM, Dannals RF (1994): Radiosynthesis of (2-bromo4, 5-dimethoxybenzyl)-7-hydroxy-6-methoxy-2-[11C]methyl-1,2,3,4-tetrahydroisoquinoline, [11C]A-69024: a non-benzazepine antagonist for studying dopamine D1 receptors in vivo using PET. J Labelled Compds Radiopharm 34:431-437

Kassiou M, Scheffel U, Ravert HT, Mathews WB, Musachio JL, Lambrecht RM, Dannals RF (1995): [11C]A-69024: a potent and selective non-benzazepine radiotracer for in vivo studies of dopamine D1 receptors. Nucl Med Biol 22:221-226

Kerkman DJ, Ackerman M, Artman LD, MacKenzie RG, Johnson MC, Bednarz L, Montana W, Asin KE, Stampfli H, Kebabian JW (1989): A-69024: a non-benzazepine antagonist with selectivity for the dopamine D-1 receptor. Eur J Pharmacol 166: 481-491

Khawaja X, Evans N, Reilly Y, Ennis C, Minchin MC, (1995): Characterisation of the binding of [3H]WAY-100635, a novel 5-hydroxytryptamine-1A receptor antagonist, to rat brain. J Neurochem 64:2716-2726

Kohler C, Hall H, Ogren SO, Gawell L (1985): Specific in vitro and in vivo binding of $3 \mathrm{H}$-raclopride. A potent substituted benzamide drug with high affinity for dopamine D-2 receptors in the rat brain. Biochem Pharmacol 34:2251-2259

Kuczenski R, Segal DS (1992): Differential effects of amphetamine and dopamine uptake blockers (cocaine, nomifensine) on caudate and accumbens dialysate dopamine and 3-methoxytyramine. J Pharmacol Exp Ther 262:1085-1094

Kung HF, Pan S, Kung MP, Billings J, Kasliwal R, Reilley J, Alavi A (1989): In vitro and in vivo evaluation of [123I]IBZM: a potential CNS D-2 dopamine receptor imaging agent. J Nucl Med 30:88-92

Laruelle M (2000): Imaging synaptic neurotransmission with in vivo binding competition techniques: a critical review. J Cereb Blood Flow Metab 20:423-451

Laruelle M, Abi-Dargham A, van Dyck $\mathrm{CH}$, Rosenblatt W, Zea-Ponce Y, Zoghbi SS, Baldwin RM, Charney DS, Hoffer PB, Kung HF, et al. (1995): SPECT imaging of striatal dopamine release after amphetamine challenge. J Nucl Med 36:1182-1190

Laruelle M, Iyer RN, al-Tikriti MS, Zea-Ponce Y, Malison R, Zoghbi SS, Baldwin RM, Kung HF, Charney DS, Hoffer PB, Innis RB, Bradberry CW (1997): Microdialysis and SPECT measurements of amphetamine-induced dopamine release in nonhuman primates. Synapse 25:1-14

Lyon RA, Titeler M, Frost JJ, Whitehouse PJ, Wong DF, Wagner Jr HN, Dannals RF, Links JM, Kuhar MJ (1986): 3H3-N-methylspiperone labels D2 dopamine receptors in basal ganglia and S2 serotonin receptors in cerebral cortex. J Neurosci 6:2941-2949

Mennini T, Bizzi A, Caccia S, Codegoni A, Fracasso C, Frittoli E, Guiso G, Padura IM, Taddei C, Uslenghi A, et al. (1991): Comparative studies on the anorectic activity of d-fenfluramine in mice, rats, and guinea pigs. NaunynSchmiedeberg's Arch Pharmacol 343:483-490

Morgan AE, Porter SP, Clarkson FA, Volkow ND, Fowler JS, Dewey SL (1997): Direct approach for attenuating cocaine's effects on extracellular dopamine: targeting the dopamine transporter. Synapse 26:423-427

Nyberg S, Farde L, Eriksson L, Halldin C, Eriksson B (1993): 5-HT2 and D2 dopamine receptor occupancy in the living human brain: A PET study with risperidone. Psychopharmacology 110:265-272

Pike VW, McCarron JA, Lammertsma AA, Osman S, Hume SP, Sargent PA, Bench CJ, Cliffe IA, Fletcher A, Grasby PM (1996): Exquisite delineation of 5-HT1A receptors in human brain with PET and [carbonyl-11 C]WAY100635. Eur J Pharmacol 301:R5-7

Plenevaux A, Weissmann D, Aerts J, Lemaire C, Brihaye C, Degueldre C, Le Bars D, Comar D, Pujol J, Luxen A (2000): Tissue distribution, autoradiography, and metabolism of 4-(2'-methoxyphenyl)-1-[2' -[N-(2'"pyridinyl)-p-[(18)F] fluorobenzamido]ethyl]piperazine (p-[(18)F]MPPF), a new serotonin 5-HT(1A) antagonist for positron emission tomography: An in vivo study in rats. J Neurochem 75:803-811

Raiteri M, Bonanno G, Vallebuona F (1995): In vitro and in vivo effects of d-fenfluramine: no apparent relation between 5-hydroxytryptamine release and hypophagia. J Pharmacol Exp Ther 273:643-649

Ross SB (1991): Synaptic concentration of dopamine in the mouse striatum in relationship to the kinetic properties of the dopamine receptors and uptake mechanism. J Neurochem 56:22-29.

Ross SB, Jackson DM (1989a): Kinetic properties of the accumulation of $3 \mathrm{H}$-raclopride in the mouse brain in vivo. Naunyn-Schmiedeberg's Arch Pharmacol 340:6-12. 
Ross SB, Jackson DM (1989b): Kinetic properties of the in vivo accumulation of $3 \mathrm{H}-(-)-\mathrm{N}-\mathrm{n}-$ propylnorapomorphine in mouse brain. Naunyn-Schmiedeberg's Arch Pharmacol 340:13-20.

Swart JA, van der Werf JF, Wiegman T, Paans AM, Vaalburg W, Korf J (1990): In vivo binding of spiperone and $\mathrm{N}$-methylspiperone to dopaminergic and serotonergic sites in the rat brain: multiple modeling and implications for PET scanning. J Cereb Blood Flow Metab 10:297-306.

Thibaut F, Vaugeois JM, Bonnet JJ, Costentin J (1996): In vivo striatal binding of the D1 antagonist SCH 23390 is not modified by changes in dopaminergic transmission. Neuropharmacology 35:267-272.

Volkow ND, Wang GJ, Fowler JS, Logan J, Gatley SJ, Wong C, Hitzemann R, Pappas NR (1999): Reinforcing effects of psychostimulants in humans are associated with increases in brain dopamine and occupancy of $\mathrm{D}(2)$ receptors. J Pharmacol Exp Ther 291:409-415.

Volkow ND, Wang GJ, Fowler JS, Logan J, Schlyer D, Hitzemann R, Lieberman J, Angrist B, Pappas N, MacGregor $R$, et al. (1994): Imaging endogenous dopamine competition with [11C]raclopride in the human brain. Synapse 16:255-262.

Wang GJ, Volkow ND, Logan J, Fowler JS, Schlyer D, MacGregor RR, Hitzemann RJ, Gur RC, Wolf AP (1995): Evaluation of age-related changes in serotonin 5-HT2 and dopamine D2 receptor availability in healthy human subjects. Life Sci 56:L249-253.

Young LT, Wong DF, Goldman S, Minkin E, Chen C, Matsumura K, Scheffel U, Wagner Jr HN (1991): Effects of endogenous dopamine on kinetics of [3H]N-methylspiperone and $[3 \mathrm{H}]$ raclopride binding in the rat brain. Synapse 9:188-194. 